TECHNICAL BULLETIN NO. 98-7 IDAHO BUREAU OF LAND MANAGEMENT APRIL 1998

\title{
AN ILLUSTRATED GUIDE TO THE
}

SPECIAL STATUS PLANTS

OF THE

SHOSHONE RESOURCE AREA

(UPPER SNAKE RIVER DISTRICT)

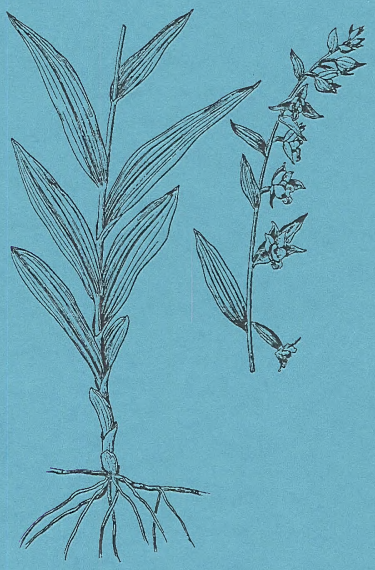

Compiled by

Paul B. $\mathrm{M}^{\mathrm{C}}$ Clain 

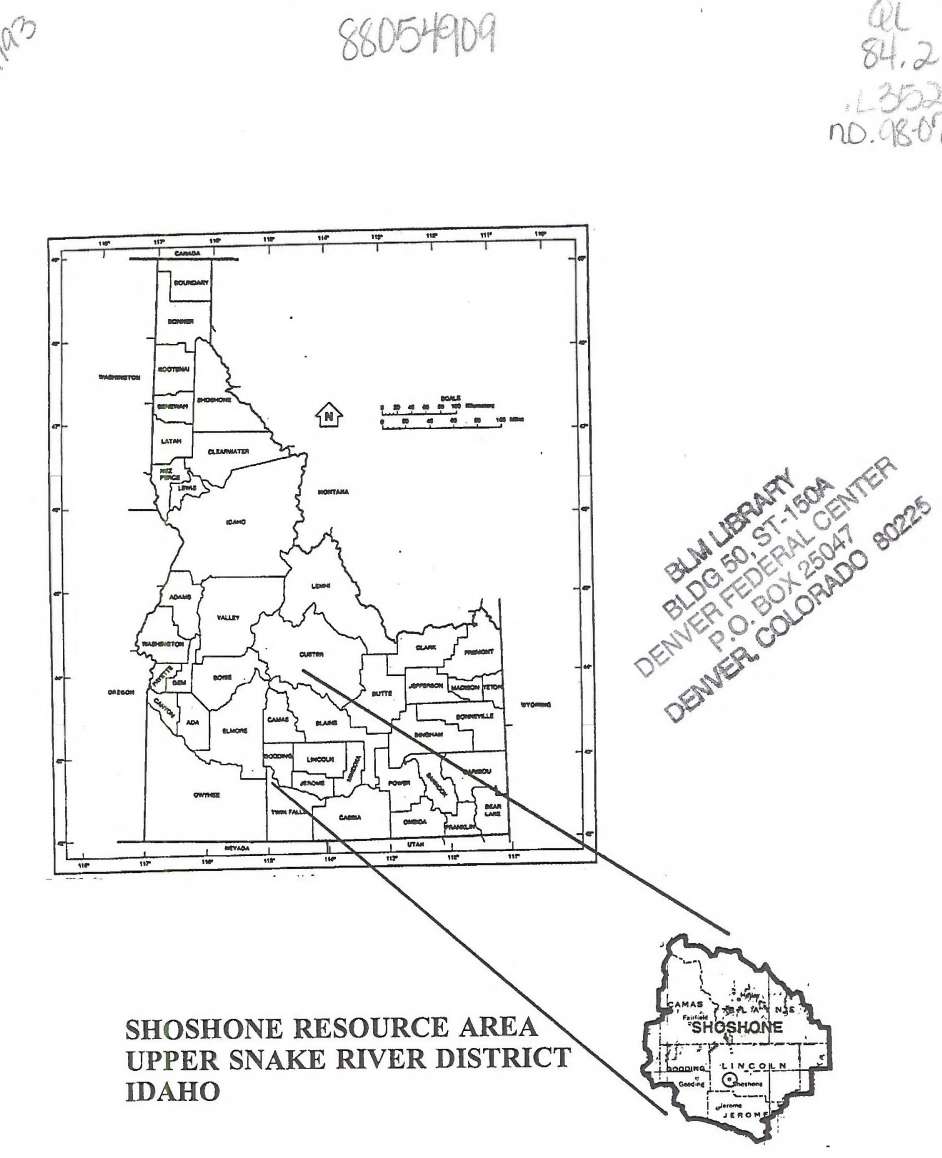


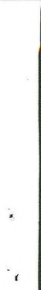




\section{INTRODUCTION}

This collection of information includes all known or suspected sensitive plant species that may be found on or adjacent to public lands within the influence of the Shoshone Resource Area, Upper Snake River District.

The plants are arranged in alphabetical order by genus. An index of common names has been included for those unfamiliar with Latin names.

Plant nomenclature generally follows that of Cronquist et. al. in their Intermountain Flora $(1972$ - present). As this flora is not yet complete nomenclature for those species not covered follows Hitchcock and Cronquist in their Flora of the Pacific Northwest (1973). There are several exceptions to this generalization including: Cypripedium parviflorum var. pubescens (published in Rhodora, 1993), Lepidium papilliferum (published by Rollins in Cruciferaceae of Continental North America), Eriogonum salicornioides, Mentzelia congesta, and the lichen Texosporium sancti-joacbi. Other sources of information include: $A n$ Illustrated Guide to the Sensitive Plants of the Boise District Bureau of Land Management, Technical Bulletin 88-4, An Illustrated Guide to the Sensitive Plants of Burley District Bureau of Land Managment, Technical Bulletin 89-3, Sensitive Plants of the Jarbidge Resource Area, Technical Bulletin 96-7, and Conservation Status of Least Phacelia (Phacelia minutissima), Technical Bulletin 95-7. Illustrations are from a variety of sources including the above, Threatened and Endangered Plants of Nevada - An Illustrated Manual (1980), and U.S.Forest Service Sensitive Plant Field Guides.

The target group for this guide is non-botanical specialists with some formal training in botany. Therefore, an attempt has been made to straddle the fence between purely technical and non-technical terminology.

The primary danger of using this type of guide is in assuming that because a species is not listed here it can't or doesn't occur in the area covered. That thought process would eliminate the possibility of finding species not previously identified in an area or species expanding their range.

\section{Conservation Status Definitions:}

Globally Rare $=$ Species and varieties (taxa) rare throughout their range.

$\mathrm{G}=$ Global rank indicator; denotes rank based on rangewide status.

$\mathrm{T}=$ Trinomial rank indicator; denotes rangewide status of variety or subspecies.

$\mathrm{X}=$ Considered extinct throuthout its range.

$1=$ Critically imperiled because of extreme rarity or because of some factor of its biology making it especially vulnerable to extinction (typically 5 or fewer occurrences).

2 = Imperiled because of rarity or because of other factors demonstrably making it very vulnerable to extinction (typically 6 to 20 occurrences). 
$3=$ Rare or uncommon, but not imperiled (typically 21 to 100 occurrences).

$4=$ Not rare and apparently secure, but with cause for long-term concern (usually more than 100 occurrences).

5 = Demonstrably widespread, abundant, and secure.

State Rare Species $=$ Taxa rare within the political boundaries of Idaho, but more common elsewhere.

SP1 $=$ State Priority $1=\mathrm{A}$ taxon in danger of becoming extinct or extirpated from Idaho in the foreseeable future if identifiable factors contributing to its decline continue to operate; these are taxa whose populations are present only at critically low levels or whose habitats have been degraded or depleted to a significant degree.

SP2 $=$ State Priority $2=$ A taxon likely to be classified as Priority 1 within the foreseeable future in Idaho, if factors contributing to its population decline or habitat degradation or loss continue.

SS $=$ State Sensitive $=\mathrm{A}$ taxon with small populations or localized distributions within Idaho that presently do not meet the criteria for classification as Priority 1 or 2 , but whose populations and habitats may be jeopardized without active management or removal of threats.

$\mathrm{SM}=$ State Monitor $=$ Taxa that are common within a limited range as well as those taxa which are uncommon, but have no identifiable threats (for example, certain alpine taxa).

Review Species $=$ Global and State rare taxa which may be of conservation concern in Idaho, but for which we have insufficient data upon which to base a recommendation regarding their appropriate classification.

BLM Sensitive $=$ Species of plants and animals in Idaho whose populations are consistently small and widely dispersed, or whose ranges are restricted to a few locations such that any appreciable reduction in number, habitat availability, or habitat condition might lead towards extinction. This classification is the result of a Memorandum of Understanding between the Bureau of Land Management (in Idaho) and the Idaho Department of Fish and Game.

\section{Acknowledgements}

A special thanks goes to Roger Rosentreter and Ann DeBoldt for their review and editing of this guide. Without their help the final product would have been poor indeed. 


\section{LIST OF SPECIAL STATUS PLANTS IN OR NEAR THE SHOSHONE F.O.}

$\underline{\text { Scientific Names }}$

Allium anceps

Ancistrocarphus filagineus (Stylocline filaginea)

Antennaria arcuata

Astragalus atratus var. inseptus

Astragalus oniciformis

Astragalus purshii var. ophiogenes

Calandrinia ciliata

Carex buxbaumii

Cypripedium parviflorum var. pubescens

Downingia bacigalupii

Eatonella nivea

Epipactis gigantea

Eriogonum salicornioides

Gymnosteris nudicaulis

Gymnosteris parvula

Haplopappus insecticruris

Lepidium papilliferum

Lithophragma tenella var, thompsonii

Machaerocarpus californicus

Mentzelia congesta

Pectocarya setosa

Phacelia inconspicua

Phacelia minutissima

Poa leibergii

Primula cusickiana

Sphaeromeria potentilloides

Spiranthes diluvialis

Sporobolus asper

Texosporium sancti-jacobi
Common Names

Two-headed onion

Hooked stylocline

Meadow (arching) pussytoes

Mourning milkvetch

Picabo milkvetch

Snake River milkvetch

Red maids

Buxbaum's sedge

Small yellow lady's slipper

Bacigalupi's downingia

White eatonella

Giant helleborine (chatterbox orchid)

Annual salt eriogonum

Large-flowered gymnosteris

Small-flowered gymnosteris

Bugleg goldenweed

Slick-spot peppergrass

Prairie star

Fringed waterplantain

United blazingstar

Combseed (bristly pectocarya)

Obscure (inconspicuous) phacelia

Least phacelia

Leiberg bluegrass

Cusick's primrose

Cinquefoil tansy

Ute lady's tresses

Tall (rough) dropseed

Woven-spore lichen 


\section{ALPHABETICAL LISTING OF PLANTS BY COMMON NAME}

\section{Common Names}

Annual salt eriogonum

Arching pussytoes

Bacigalupi's downingia

Bristly pectocarya

Bugleg goldenweed

Buxbaum's sedge

Chatterbox orchid

Cinquefoil tansy

Combseed

Cusick's primrose

Fringed waterplantain

Giant helleborine

Hooked stylocline

Inconspicuous phacelia

Large-flowered gymnosteris

Least phacelia

Leiberg bluegrass

Meadow pussytoes

Mourning milkvetch

Obscure phacelia

Picabo milkvetch

Prairie star

Red maids

Slick-spot peppergrass

Small-flowered gymnosteris

Small yellow lady's slipper

Snake River milkvetch

Rough dropseed

Tall dropseed

Two-headed onion

United blazingstar

Ute lady's tresses

White eatonella

Woven-spore lichen $\underline{\text { Scientific Names }}$

Eriogonum salicornioides

Antennaria arcuata

Downingia bacigalupii

Pectocarya setosa

Haplopappus insecticruris

Carex buxbaumii

Epipactis gigantea

Sphaeromeria potentilloides

Pectocarya setosa

Primula cusickiana

Machaerocarpus californicus

Epipactis gigantea

Ancistrocarphus filagineus

Phacelia inconspicua

Gymnosteris nudicaulis

Phacelia minutissima

Poa leibergii

Antennaria arcuata

Astragalus atratus var. inseptus

Phacelia inconspicua

Astragalus oniciformis

Lithophragma tenella var. thompsonii

Calandrinia ciliata

Lepidium papilliferum

Gymnosteris parvula

Cypripedium parviflorum var. pubescens

Astragalus purshii var. ophiogenes

Sporobolus asper

Sporobolus asper

Allium anceps

Mentzelia congesta

Spiranthes diluvialis

Eatonella nivea

Texosporium sancti-jacobi

A few species on this page are listed more than once because they have more than one common name. 


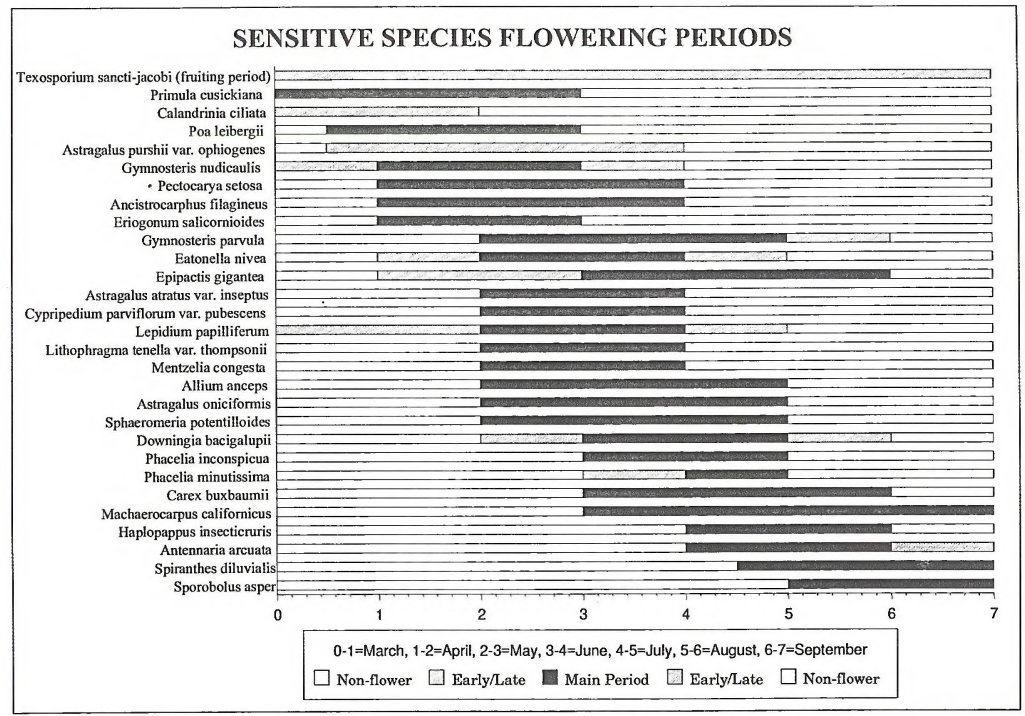




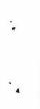


Scientific Name: Allium anceps Kellogg

Common Name: Two-headed onion

Family (Common Name): Liliaceae (Lily Family)

Status: BLM Sensitive Species, ID State Priority 2 Species

Flowering Period: May to July

Habitat: Heavy barren soils of volcanic origin in swales, on flats, and slopes in the foothills and lowlands, where water stands in the spring; $1500-1600 \mathrm{~m}\left(4600^{\prime}-5050^{\prime}\right)$ elevation.

Associates: Artemisia arbuscula (low sage), Eriogonum microthecum, Astragalus calycosus.

Key Characteristics: Perennial; tepals pinkish with a diffuse green midrib, 6-10 mm long, slender, linear to lance-linear; leaves two, flattened; inflorescence an umbel with 15-25 flowers, the pedicels 3 times as long as the perianth or longer; bulb broadly ovoid, the coats thick and yellow with thick reticulations.

Threats: Range improvement projects.

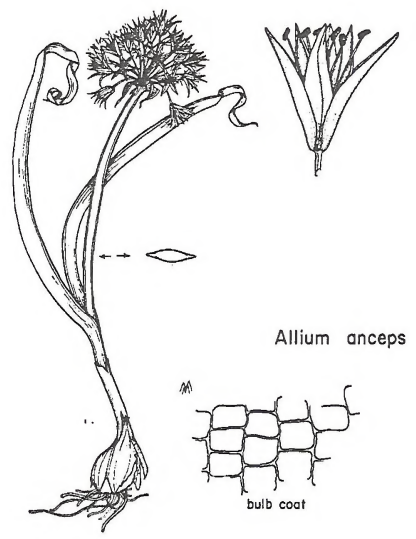




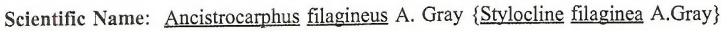

Common Name: Hooked stylocline

Family (Common Name): Asteraceae (Sunflower Family)

Status: BLM Sensitive Species and ID State Monitor Species

Flowering Period: April to June

Habitat: Level flats on terraces with little or no drainage, relatively barren sites of cinder over shallow basalt bedrock. Open, dry or vernally moist places at mid-elevations of $600 \mathrm{~m}$ to $1900 \mathrm{~m}\left(1900^{\prime}\right.$ to $\left.5900^{\prime}\right)$.

Associates: Sites are commonly surrounded by Artemisia longiloba (alkali sage), A. papposa

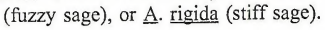

Key Characteristics: Simple to often diffusely branched, white woolly annual; low, seldom over $1 \mathrm{dm}$ tall, often eventually prostrate; leaves gray, linear to spatulate, rarely as much as 2 (3) cm long; bracts of the pistillate flowers 2-3 (4) $\mathrm{mm}$ long; inner (fishhook) bracts $\mathrm{ca} 5$, in a single series around the margin of the receptacle, $3-5 \mathrm{~mm}$ long at maturity; achenes ca 1-1.5 (2) mm long. Grows in a clump but individual plants are about $6-7 \mathrm{~mm}$ across.

Threats: Off-road vehicles, road building, and salt lick placement.
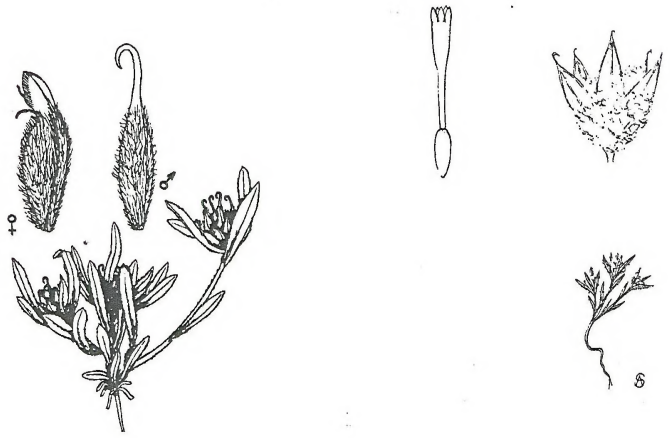
Scientific Name: Antennaria arcuata Cronq.

Common Name: Meadow (Arching) pussytoes

Family (Common Name): Asteraceae (Sunflower Family)

Status: BLM Sensitive, G2

Flowering Period: July to August (September)

Habitat: Moist or wet (not permanently) meadows (or hay-meadows), or in moist swales in sagebrush plains. Often found on top of hummocks and small, bare or moss-covered spots of soil in sedge grass meadow; sandy loam soil, 18 inches deep; $1500-2300 \mathrm{~m}$ $\left(4650^{\prime}-7100^{\prime}\right)$ elevation.

Associates: Potentilla gracilis (cinquefoil), Deschampsia caespitosa (tufted hairgrass),

Sisyrinchium douglasii (Douglas grass widow), Achillea millefolium (yarrow), and Juncus sp. (rush), Distichlis stricta (alkali saltgrass), Poa pratensis (Kentucky bluegrass), Carex spp. (sedges), Aster sp. (aster), and Castilleja sp. (Indian paintbrush).

Key Characteristics: Loosely whitewoolly perennial herb, $30-40 \mathrm{~cm}$ tall; basal leaves few, oblanceolate, equally grayish-white hairy above and below; stem leaves narrow; flower heads numerous, involucre 4-6 mm long in pistillate plants, 5$7 \mathrm{~mm}$ long in staminate plants, bracts membranous, white-tipped; disk flowers white; arching woolly stolons to $1 \mathrm{dm}$ long (hence the name).

Threats: Plowing and reseeding of meadows.

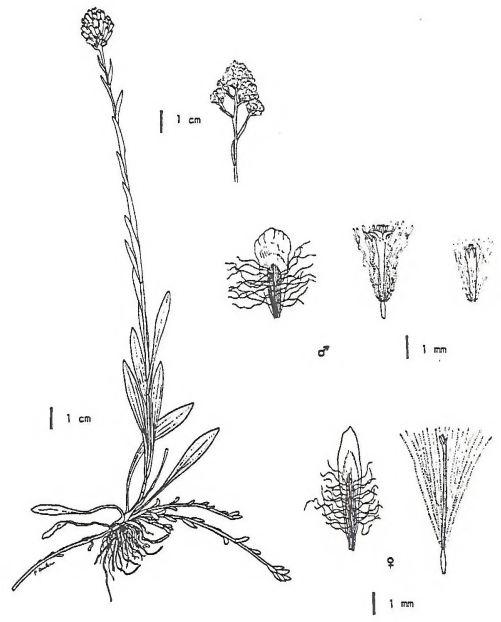


Scientific Name: Astragalus atratus var. inseptus S. Wats

Common Name: Mourning milkvetch

Family (Common Name): Fabaceae (Legume Family)

Status: BLM Sensitive Species, G4/T3

Flowering Period: Late May to June

Habitat: Found on thin, clay soil over basalt that is wet in spring but dry at other seasons. Rock tablelands and plains with clay and clay-loam soils. Below $1500 \mathrm{~m}\left(4600^{\prime}\right)$ elevation. Flats and plains to gentle slopes.

Associates: Artemisia tridentata ssp. wyomingensis (Wyoming big sagebrush), $\underline{\mathrm{A}}$. longiloba, A. tripartita, Allium acuminatum, Aster scopulorum, Poa sandbergii, Astragalus

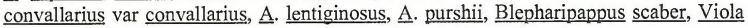
beckwithii, Helianthus annuus, Stipa spp., and Agropyron spicatum.

Key Characteristics: A wiry, perennial milkvetch; flowering stems decumbent to prostrate; leaflets 9-15, linear-oblong, terminal leaflet jointed; pod leathery and red speckled (mottled), 12-18 $\mathrm{mm}$ long and 3-4 $\mathrm{mm}$ wide; flowers white, sometimes faintly lilactinged

Threats: Livestock grazing and range "improvement" projects.

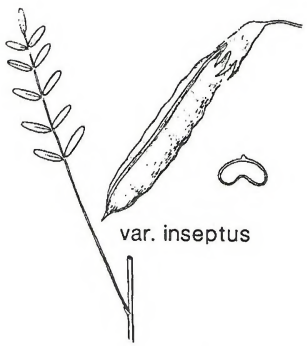


Scientific Name: Astragalus oniciformis Barneby

Common Name: Picabo milkvetch

Family (Common Name): Fabaceae (Legume Family)

Status: BLM Sensitive Species, G3

Flowering Period: May to July

Habitat: Deep stable sandy soil (not dunes), flat topography with underlying basaltic substrate. $1320-1530 \mathrm{~m}\left(4100^{\prime}-4700^{\prime}\right)$ elevation. Known only from the first foothills of the Pioneer Mts. along the northern margin of the Snake River Plains.

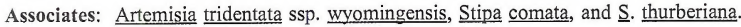

Key Characteristics: Wiry, diffuse, perennial herb, the stiff, procumbent stems (0.5) 1-2.5 $\mathrm{dm}$ tall, radiating from a superficial root-crown; pod triangular in cross-section, pendulous, stipitate, $7-12 \times \pm 2-2.5 \mathrm{~mm}$; leaflets all jointed to the rachis; stems prostrate; free stipules; pubesence of sinuous or incurved hairs.

Threats: Plow \& seed (or other tap root disturbances) and competition with exotics.

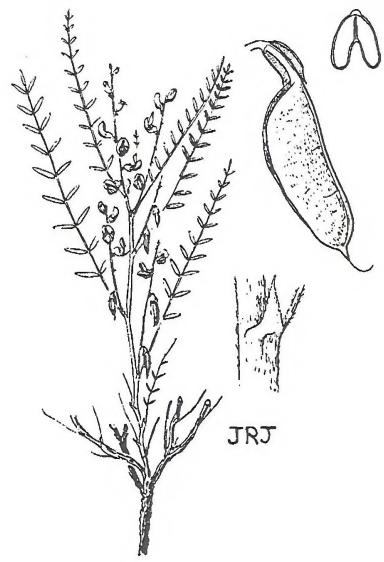


Scientific Name: Astragalus purshii var. ophiogenes Barneby

Common Name: Snake River milkvetch (… purshii aka wooly-pod milkvetch)

Family (Common Name): Fabaceae (Legume Family)

Status: BLM Sensitive, G3

Flowering Period: Spring and early summer according to latitude and elevation

Habitat: Loosely aggregated, often actively moving sand and gravelly sand deposits. Sand or gravel-sandy bluffs, talus, dunes, and volcanic ash beds, $700-1075 \mathrm{~m}\left(2200^{\prime}-3300^{\prime}\right)$ elevation. Snake River corridor, below or near the edge of the rim, from King Hill to Murtaugh.

Associates: Barren sites surrounded by Artemisia tridentata ssp. tridentata. Also Indian ricegrass, needle-and-thread grass, pale evening primrose, four-wing saltbush.

Key Characteristics: Tufted, acaulescent perennial form, leaves with 9-15 leaflets; flowers pink, 5-11 in a raceme, calyx less than $9 \mathrm{~mm}$, pod strongly in-curved, $8-13 \mathrm{~mm}$, hairy (though much less so than $\underline{\mathrm{A}}$. p. var. purshii).

Threats: Land exchanges and off-highway vehicles.

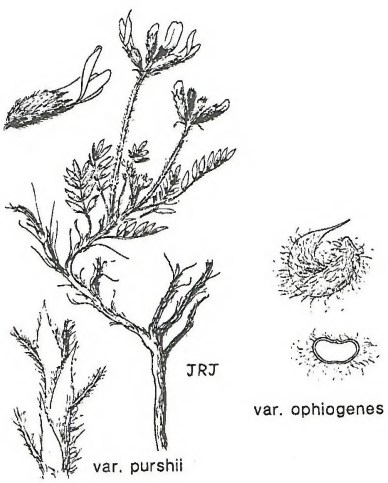


Scientific Name: Calandrinia ciliata (R. \& P.) DC.

Common Name: Red maids (Calandrinia, desert rockpurslane)

Family (Common Name): Portulacaceae (Purslane Family)

Status: Former BLM Sensitive Species, Review Species

Flowering Period: April to May

Habitat: Gravelly to heavy soil, usually where moist at least early in the season, often rather weed-like in habit.

Key Characteristics: Low spreading to erect annual; stems mostly several, simple to branched from the base, (5) 10-30 (40) $\mathrm{cm}$ long, glabrous or slightly ciliate along the angles; leaves $1.5-7 \mathrm{~cm}$ long, $2-10 \mathrm{~mm}$ broad; petals deep crimson-purple to (rarely) white. Succulent annual with 2 persistent sepals.

Threats: None identified.

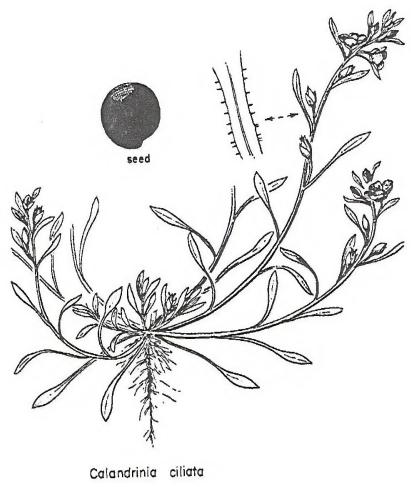


Scientific Name: Carex buxbaumii Wahlenb.

Common Name: Buxbaum's sedge

Family (Common Name): Cyperaceae (Sedge Family)

Status: BLM Sensitive Species, ID State Sensitive Species

Flowering Period: June to August

Habitat: Peat bogs, marshes, wet meadows and other wet places from near sea level on the northwest coast to moderate elevation in the mountains. Very local in sunny swamps or wet meadows at middle elevations. $1572 \mathrm{~m}$ (4875') elevation at Silver Creek Preserve.

Associates: Carex oederi, $\underline{\text { C. aurea, }} \underline{\underline{C}}$. nebraskensis, and Juncus balticus. Community types: Carex buxbaumii, Potentilla fruticosa/Deschampsia cespitosa, and Carex lanuginosa.

Key Characteristics: Plants 3-10 dm tall; lowest leaves reduced to scales; stems arising singly or few together, not surrounded by the dried sheaths of previous years; terminal spike gynaecandrous (a spike with both staminate and pistillate flowers, the staminate below the pistillate).

Threats: Livestock grazing and trampling, changes in hydrologic flows, spring developments, range "improvements."

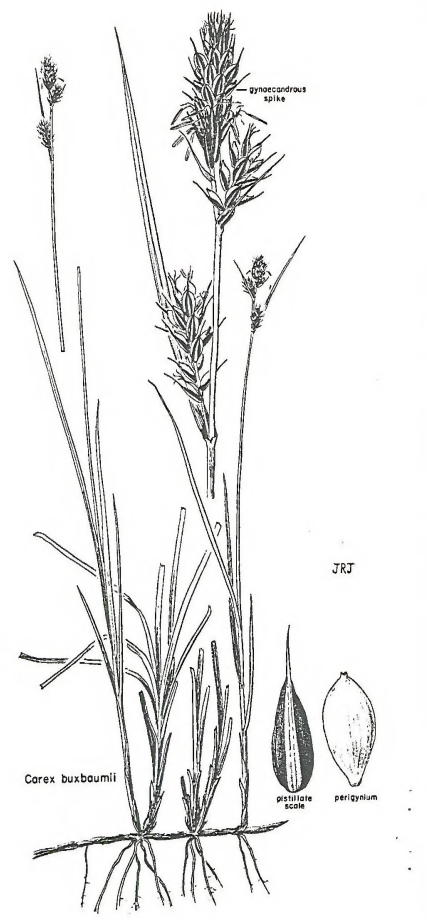


Scientific Name: Cypripedium parviflorum var. pubescens (Willd.) Knight \{Many sources continue to use the name for the Eurasian form, $\underline{C}$. calceolus L.\}

Common Name: Small yellow lady's slipper

Family (Common Name): Orchidaceae (Orchid Family)

Status: BLM Sensitive Species, ID State Priority 1 Species

Flowering Period: May to June

Habitat: Bogs to damp mossy woods and wet areas in thickets. In Blaine Co: flat, moist, shaded site. Soils clay loam, with a thick litter layer. Plants at ecotone between Populus tremuloides/Cornus sericea and Potentilla fruticulosa/Poa pratensis communities. $1574 \mathrm{~m}$ (4875') elevation.

Associates: Smilacina stellata, Habenaria hyperborea, Poa pratensis, Galium boreale, Achillea millefolium, Cornus sericea, Rosa woodsii, and Carex oederi.

Key Characteristics: Often forming clumps with several flowering stems rising from the base; stems 3-4 dm tall; leaves 3 or 4 alternate, broadly lanceolate to broadly elliptic, somewhat acuminate , $5-14 \mathrm{~cm}$ long; flowers usually solitary, but 2 on robust plants, usually exceeded by an erect, leaf-like bract; sepals and petals greenish-yellow or more often purplish-brown; lip $2-3 \mathrm{~cm}$ long, strongly pouched and of a firm, nearly coriaceous texture, yellow, often with purplish dots around the orifice.

Threats: Livestock grazing and trampling.

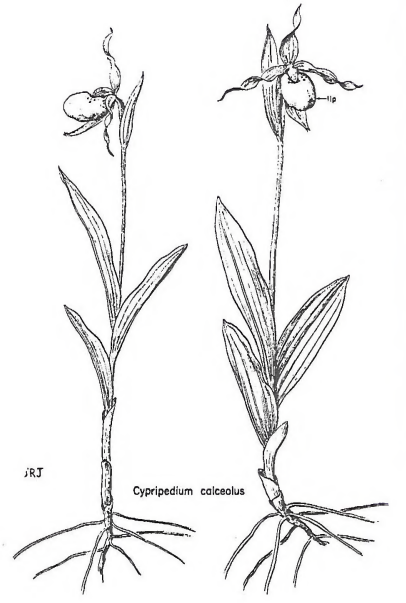


Scientific Name: Downingia bacigalupii Weiler

Common Name: Bacigalupi's downingia

Family (Common Name): Campanulaceae (Bellflower or Harebell Family)

Status: BLM Sensitive Species, ID State Priority 1 Species

Flowering Period: (May) June to July (August)

Habitat: Drying mud of vernal pools, muddy margins of lakes, wet meadows, roadside and irrigation ditches, and streambanks. $400 \mathrm{~m}$ to $2000 \mathrm{~m}\left(1200^{\prime}\right.$ to $\left.6200^{\prime}\right)$ elevation.

Key Characteristics: Plants 0.5-2.5 (4) dm tall; corollas lavender-blue, usually with prominent, more deeply colored veins, especially noticeable on the lower corolla-lobes, the lower lip with a central white area devoid of blue veins but with two bright orange-yellow spots; flowers sessile with an elongate ovary;

Threats: Livestock grazing and trampling.

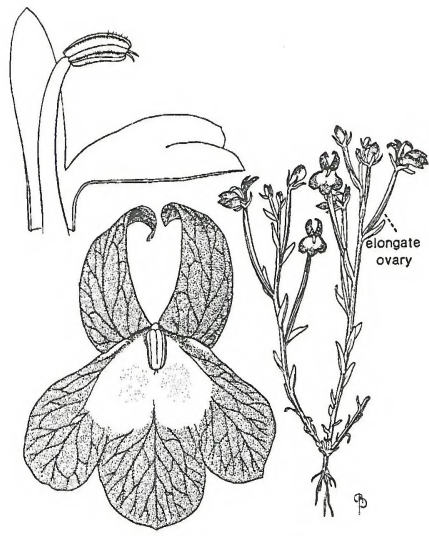

Downingia bacigalupii 
Scientific Name: Eatonella nivea (E.C. Eaton) A. Gray

Common Name: White eatonella

Family (Common Name): Asteraceae (Sunflower Family)

Status: BLM Sensitive Species and ID State Sensitive

Flowering Period: (April) May to June (July)

Habitat: Dry, cindery, sandy or volcanic desert areas, often with sagebrush; soil saturated to moist in the spring (like a vernal pool); has also been found on a steep slope above Walker Reservoir, ca 1.5 miles north of King Hill; $800 \mathrm{~m}$ to $1900 \mathrm{~m}$ (2500' to $5900^{\prime}$ ) elevation. Also found in dry washes, especially in salt desert shrub habitat.

Associates: Barren areas surrounded by Artemisia tridentata ssp. tridentata .

Key Characteristics: Depressed, diminutive white-woolly annual, branching from the base and often forming small tufts; rays yellow or purplish and only slightly longer than the involucral bracts; leaves numerous, oblanceolate to spatulate, entire, and densely woolly, appearing whitish over the green.

Threats: Off-highway vehicles and spring livestock trampling/grazing.
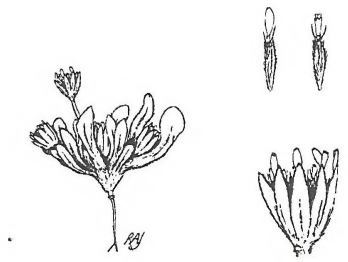
Scientific Name: Epipactis gigantea Douglas ex Hook.

Common Name: Chatterbox orchid (giant helleborine)

Family (Common Name): Orchidaceae (Orchid Family)

Status: BLM Sensitive Species, ID State Priority 1 Species

Flowering Period: (April) June to August

Habitat: Seepage areas, and bases of cliffs along streams, often associated with thermal areas. $1600-2400 \mathrm{~m}\left(5000^{\prime}-7400^{\prime}\right)$ elevation. Sites are often calcareous or well decomposed granite, often hot springs.

Associates: Mimulus spp. (monkey flower), Carex spp. (sedges), and Eleocharis spp. (spikerush)

Key Characteristics: Plants up to $1 \mathrm{~m}$ tall; flowers 3-9 (12), brownish-purple; sepals and upper petals $1.3-1.7 \mathrm{~cm}$ long, greenish-yellow or coppery with purple veins; lip petal $1.5-2 \mathrm{~cm}$ long, greenish with purple veins, deeply lobed into 3 unequal segments; inflorescence open, leafy raceme of 2-5 (or more) flowers; fruit an elliptic, drooping capsule; leaves numerous, elliptical, alternating, broad, glabrous to minutely pubescent, oval to lance-shaped, 5.5$20 \mathrm{~cm}$ long, clasping the stem.

Threats: Development and human disturbance of cold and hot springs, livestock grazing.
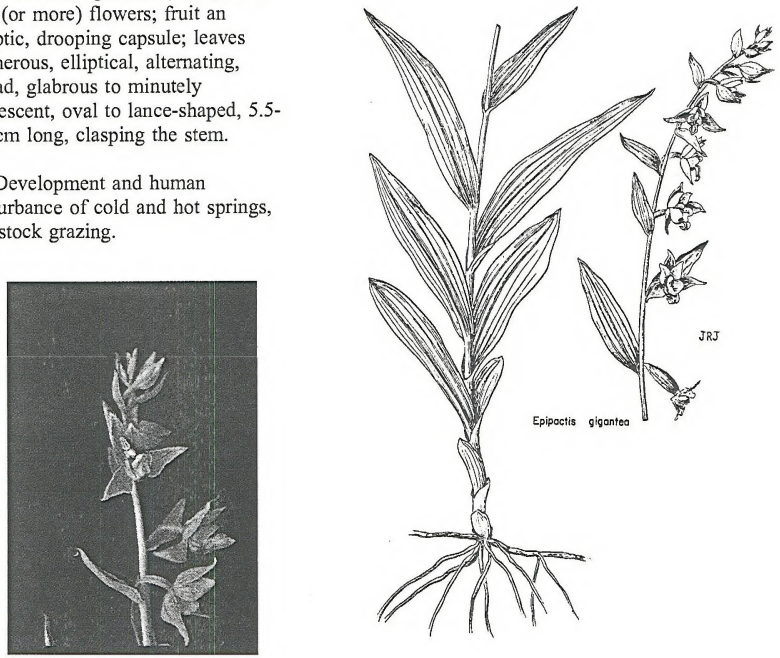
Scientific Name: Eriogonum salicornioides Gandg. \{E. vimineum ssp. baileyi var. salicornioides Stokes\}

Common Name: Annual salt buckwheat

Family (Common Name): Polygonaceae (Buckwheat Family)

Status: Former BLM Sensitive Species, Review Species

Flowering Period: April to May (June to September)

Habitat: Grows on bare, alkaline soils in shadscale-budsage and Wyoming big sagebrush habitat. Found from $840-1355 \mathrm{~m}\left(2600^{\prime}-4200^{\prime}\right)$ elevation. Loose, white, ashy clay soil. (Sandy or rocky soil)

Associates: Artemisia tridentata ssp. wyomingensis, A. spinescens, Atriplex spp., and Ambrosia spp.

Key Characteristics: An upright, non-mat forming buckwheat, freely di- or trichotomously branched annual 5-30 (40) cm tall; the erect stem arises from a cluster of basal leaves, ovate to broadly elliptical in shape, mostly gray-tomentose below and less tomentose to green above; flowers white, yellow, or pink, scattered along the length of the branched stems.

Threats: Mining, off-highway vehicles.

Comments: Photo and drawings are of plants described as E. vimineum var. baileyi, which may be the same plant as $\underline{E}$. salicornoides. From the limited amount of information available a main difference may be the ealier flowering period and heavier soil associated with $\underline{E}$. salicornioides.
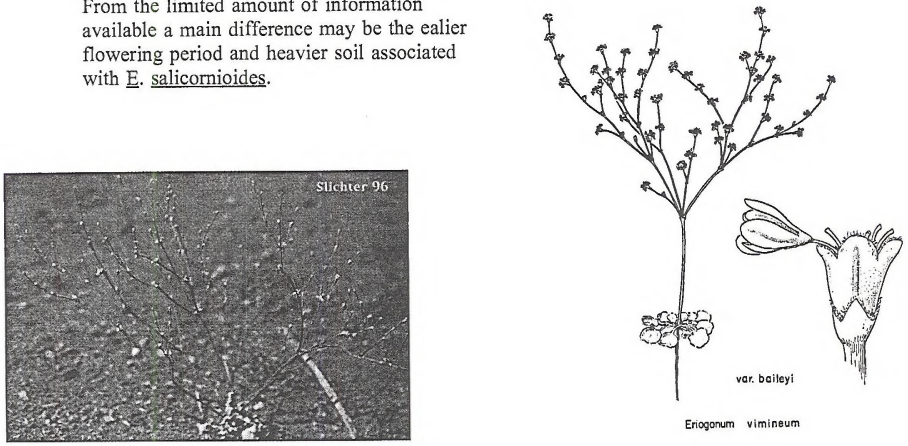
Scientific Name: Gymnosteris nudicaulis (Hook. \& Arn.) Green

Common Name: Large-flowered gymnosteris

Family (Common Name): Polemoniaceae (Phlox Family)

Status: Former BLM Sensitive Species

Flowering Period: (March) April to May (June)

Habitat: A weak-stemmed annual that grows in dry, open, sandy areas in the basin big sagegrassland zone of the plains and foothills. $870-1600 \mathrm{~m}\left(2700^{\prime}-5000^{\prime}\right)$ elevation. Sandy to sandy loam soils, often on volcanic rock. Often associated with good range condition habitats.

Associates: Artemisia tridentata ssp. tridentata

Key Characteristics: Plants 2-10 $\mathrm{cm}$ tall, simple or with a pair of basal branches; flowers showy, white or yellow, or white or lavender with a yellow eye, the tube $6-10 \mathrm{~mm}$ long; short naked stem; whorl of entire, linear or lanceolate bracteal leaves just beneath the flower cluster.

Threats: Agricultural development, land exchanges, range improvement programs, and competition with cheatgrass and other exotics.

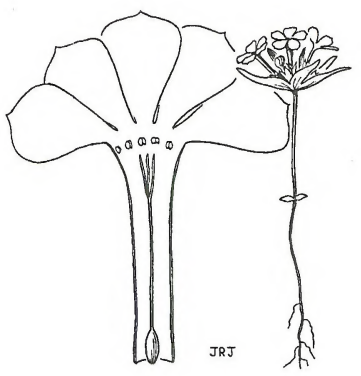


Scientific Name: Gymnosteris parvula A.A. Heller

Common Name: Small-flowered gymnosteris

Family (Common Name): Polemoniaceae (Phlox Family)

Status: Former BLM Sensitive Species

Flowering Period: May to July (August)

Habitat: Open, dry to moderately moist slopes, flats, and drier meadows, from the foothills and adjacent plains to moderate or even high elevations in the mountains (up to 2600 $\mathrm{m}$ in California), sometimes above timberline, and generally in moister places and/or at higher elevation than $\underline{G}$. nudicaulis. Generally from $1740-1900 \mathrm{~m}\left(5400^{\prime}-5900^{\prime}\right)$ in our area. Shallow, loamy to somewhat cindery or sandy soils.

Associates: Artemisia tridentata ssp. tridentata, Agropyron spicatum, and $\underline{\text { Poa sandbergii. }}$

Key Characteristics: Plants $0.7-4 \mathrm{~cm}$ tall, simple or occasionally branched at the base, often with a single flower in small individuals; flowers inconspicuous, white to pinkish, sometimes with a yellow eye, the tube $2.5-5 \mathrm{~mm}$ long; whorl of bracteal leaves, narrowly lanceolate to ovate, $3-13 \mathrm{~mm}$ long.

Threats: Trampling by grazing, agricultural development, off-road vehicles, competition with cheatgrass and other exotics.

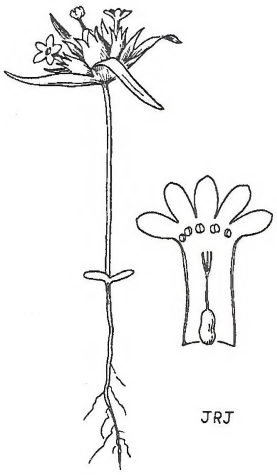


Scientific Name: Haplopappus insecticruris Henderson

Common Name: Bugleg goldenweed

Family (Common Name): Asteraceae (Sunflower Family)

Status: BLM Sensitive Species, G3

Flowering Period: July to August

Habitat: Gravelly to heavy clay soil in sagebrush-grass meadows, rolling sagebrush hills, and dry flats. Areas that are moist early and then dry out (ephemerally moist); open weak/shallow drainage or head of drainage. Also along fence lines, roads, and in old fields. Heavy clay soil. $1500 \mathrm{~m}$ to $1700 \mathrm{~m}\left(4600^{\prime}\right.$ to $\left.5300^{\prime}\right)$ elevation. Especially in Camas Prairie, Wood River Valley, and Muldoon Creek areas. Doesn't do well in thick grass.

Associates: Tends to grow between Camassia quamash (camas), on an adjacent wetter microsite, and Perideridia sp. (yampah) and Wyethia sp. (mule's-ears), on an adjacent dryer microsite.

Key Characteristics: Basal leaves very rough on their edge (like a grasshopper's leg...hence the name); cauline leaves differing in shape and edge from the basal leaves; rays yellow, 10-12 mm long; involucre 10-15 mm high; taprooted perennial, mostly 3-6 dm tall.

Threats: Shallow disturbance such as scraping may be tolerated but deep disturbance will likely kill the plant. Competition with exotics, sodforming grasses.
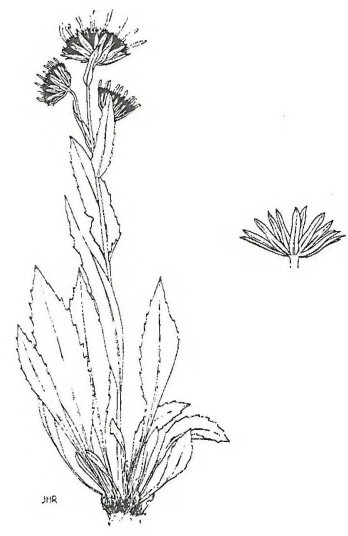
Scientific Name: Lepidium papilliferum (L. Henderson) Nels. \& Macbr.

Common Name: Slick-spot peppergrass

Family (Common Name): Brassicaceae (Mustard Family)

Status: BLM Sensitive Species, G2

Flowering Period: (March) May to June (July)

Habitat: Found in 'slick spots' (small playettes) in Wyoming big sagebrush, undisturbed playas or vernal pools. Soils usually bare, shallow and somewhat salty. Up to 1780 m (5800') elevation. Also bitterbrush communities on lacustrine sands.

Associates: Artemisia tridentata ssp. wyomingensis (Wyoming big sagebrush).

Key Characteristics: Herbaceous annual, winter annual, or in some instances biennial, leaves pinnately compound, few on stem; petals white, 3-4 mm long; stems 1 to several, simple to freely branched, usually forming a rounded plant (1) 2-4 dm tall; silicles ovate to ovate-elliptic, $2.5-3 \mathrm{~mm}$ long, the margins very narrowly winged but not upturned, shallowly emarginate at the tip, glabrous.

Threats: Livestock trampling

(especially when soils are wet), salt lick placement, agricultural development, range projects (esp. water trough placement), and military training activities.

Note: This species has not been found in the Shoshone Resource Area to date.

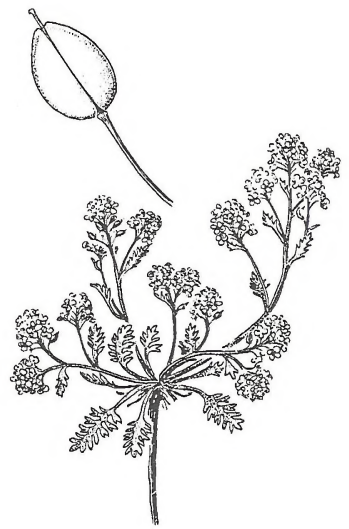


Scientific Name: Lithophragma tenella var. thompsonii (Hoover) Hitchc.

Common Name: Prairie star

Family (Common Name): Saxifragaceae (Saxifrage Family)

Status: Former BLM Sensitive Species, Review Species

Flowering Period: May to June

Habitat: Sagebrush desert to pine forest.

Key Characteristics: Plants 10-25 (30) cm tall, rather copiously glandular-pubescent with yellowish-tipped hairs; flowers 5-10, the inflorescence at first congested but very soon elongate and plainly racemose (in var. tenella the inflorescense is more panicle like); the lower pedicels often 1.5 times as long as the fruiting calyx (in var. tenella they are rarely more than 1.25 times as long); basal leaves lobed no more than half their length (in var. tenella they are generally divided or lobed almost or quite the full length).

Threats: None identified.
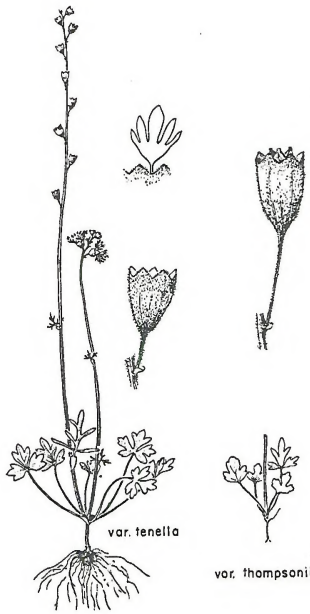

vor, thompsonii 
Scientific Name: Machaerocarpus californicus (Torr. ex Benth.) Small

Common Name: Fringed waterplantain

Family (Common Name): Alismataceae (Water-plantain Family)

Status: BLM Sensitive, ID State Monitor Species

Flowering Period: June to September

Habitat: Aquatic or amphibious herbaceous perennials. Infrequent in vernal pools, on margins of intermittent streams, sloughs, and on mud flats in marshy places.

Associates: Eleocharis palustris, Carex spp., Alisma spp.

Key Characteristics: Monotypic genus. Scapose with erect, spreading or floating basal leaves; flowers several in bracteate umbels or more commonly in few-whorled panicles, rather showy, perfect; sepals greenish, persistent; petals white or rarely pinkish, irregularly toothed or fimbriate, deciduous; stamens 6; pistils (6) 6-15 in a single whorl; fruits flattened achenes, strongly ribbed with an erect beak about as long as the body.

Threats: Livestock trampling and loss of aquatic habitat.

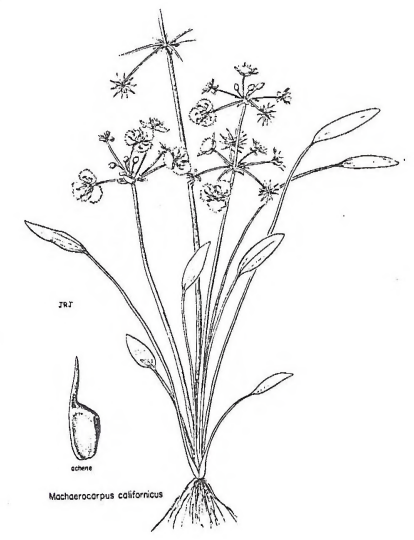


Scientific Name: Mentzelia congesta (Nutt.) T.\& G.

Common Name: United blazingstar

Family (Common Name): Loasaceae (Blazing-star Family)

Status: Former BLM Sensitive Species, Review Species

Flowering Period: May to June.

Habitat: Dry hills, sandy soils. Sagebrush scrub, pinyon-juniper woodland, northern juniper

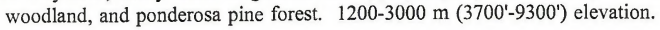

Key Characteristics: Annual plants with erect stems 1-4 dm tall, dichotomously branched, straw colored to white; leaves sessile, lanceolate to linear-lanceolate, entire to pinnatifid, 5-7 cm long, covered with glochidiate (barbed at the tip) hairs; flowers sessile, congested at the ends of the branches, subtended by conspicuous bracts; petals 5 , pale yellow above, orange below, obovate, $4-5 \mathrm{~mm}$ long; stamens about 20 .

Threats: None identified.

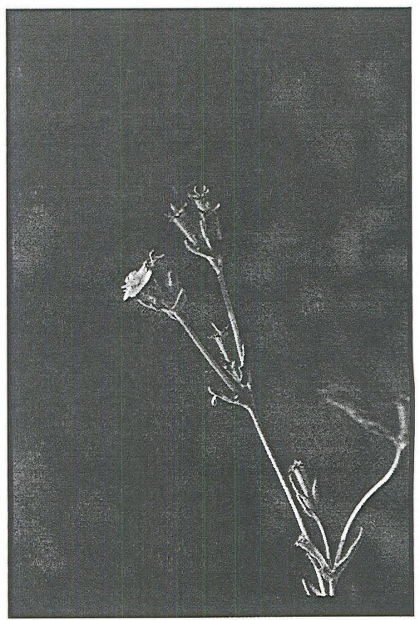


Scientific Name: Pectocarya setosa A. Gray

Common Name: Combseed (bristly pectocarya)

Family (Common Name): Boraginaceae (Borage Family)

Status: Former BLM Sensitive Species, Review Species

Flowering Period: April to June

Habitat: Dry, open places in the lowlands, commonly with sagebrush.

Associates: Artemisia tridentata ssp. tridentata

Key Characteristics: More or less branched, mostly erect or ascending annual up to 1 (2) $\mathrm{dm}$ tall, the herbage often bristly; leaves linear up to $2(3) \mathrm{cm}$ long and $2 \mathrm{~mm}$ wide, the basal and lowermost cauline ones opposite, the others alternate; calyx segments conspicuously and pungently spreading-setose (covered with bristles) and strigulose (bearing minute, straight, stiff, sharp, appressed hairs); nutlets spreading in pairs, generally 1 member of each pair with well developed, spreading wing-margins, the other nearly marginless and partly concealed by the margined one, uncinate (hooked at the tip) bristles more or less scattered over the dorsal surface.

Threats: None identified.

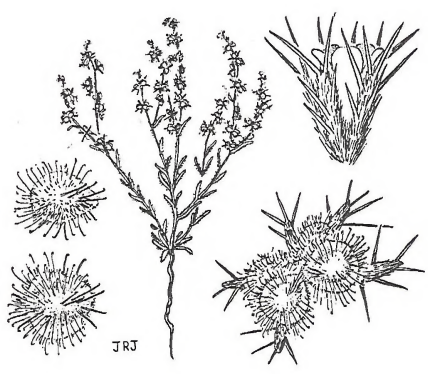


Scientific Name: Phacelia inconspicua Greene

Common Name: Obscure phacelia (inconspicuous phacelia)

Family (Common Name): Hydrophyllaceae (Waterleaf Family)

Status: BLM Sensitive Species, G1

Flowering Period: June to July

Habitat: Rocky or bare, northerly facing slopes of sagebrush/grass. Microsite often lacks other vegetation. Sites may be late melting snow drift areas. Soil loose and rich in organic matter, sandy. $1535-2415 \mathrm{~m}\left(5030^{\prime}-7920^{\prime}\right)$ elevation.

Associates: Symphoricarpos spp., Populus tremuloides, Prunus virginiana, Artemisia tridentata, Hydrophyllum occidentale, Microsteris gracilis, Galium bifolium.

Key Characteristics: An erect stemmed annual up to 1.5 (2) dm tall, freely branching from the base; flowers tubular-bell shaped, whitish short-pedicellate or subsessile in bractless, helicoid cymes; calyx segments $3 \mathrm{~mm}$ long with linear, pubescence; corolla lobes are erect and not spreading: capsule ovoid, tapered to a short beak, $3 \mathrm{~mm}$ long, somewhat pubescent, producing 4 seeds.

Threats: Mining activity.
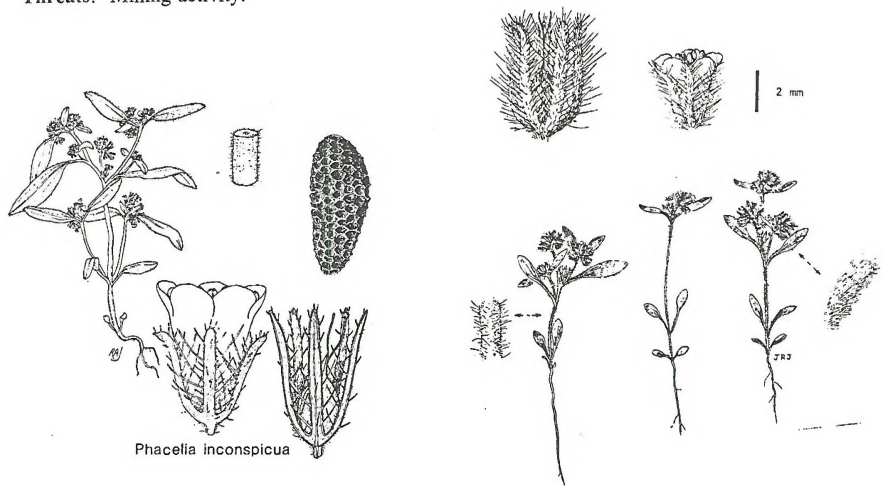

$1 \mathrm{~cm}$ 
Scientific Name: Phacelia minutissima L.F. Henderson

Common Name: Least phacelia

Family (Common Name): Hydrophyllaceae (Waterleaf Family)

Status: BLM Sensitive Species, G3

Flowering Period: July

Habitat: Ephemerally moist, bare-soil areas of riparian zones and meadows in sagebrushsteppe and lower montane forest. Many sites are seepage or snow accumulation sites. 1300-2600 m (4000'-8100') elevation.

Associates: Veratrum californicum, Populus tremuloides, annuals.

Key Characteristics: Dwarf, branching annual (approx. 3 week life-span) to $10 \mathrm{~cm}$ tall; flowers are lavender, 2.4-4 mm long, surrounded by calyx segments that elongate unequally in fruit; leaves linear-oblong to oblanceolate, $10 \mathrm{~mm}$ long by up to $4 \mathrm{~mm}$ wide; inflorescence a helicoid cyme (it uncurls like a fiddle neck).

Threats: None identified.

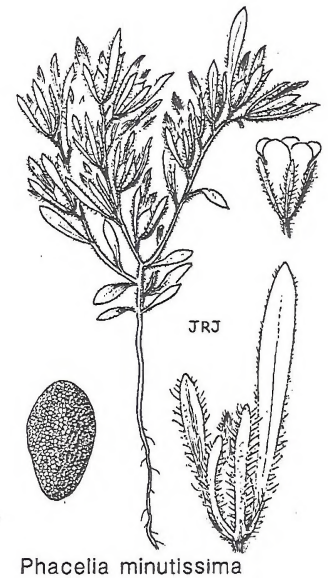


Scientific Name: Poa leibergii Scribn.

Common Name: Leiberg bluegrass

Family (Common Name): Poaceae (Grass Family)

Status: Potential Sensitive Species based on rarity in Idaho.

Flowering Period: Late March to May.

Habitat: Moist meadows and rocky slopes with heavy clay soil from the sagebrush zone to the western juniper zone.

Associates: Haplopappus insecticruris, Wyethia spp.

Key Characteristics: Small densely tufted perennials; culms 05.-2.5 (4) dm tall; leaves nearly all basal; spikelets 3-7 flowered, strongly compressed, usually purplish; lemmas not webbed at base, smooth or scaberulous; blades involute, less than $10 \mathrm{~cm}$ long.

Threats: Livestock grazing and trampling.

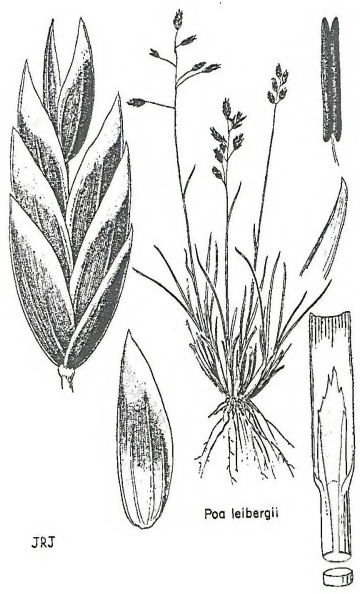


Scientific Name: Primula cusickiana Gray (There is ongoing evaluation of this species that leads some authorities (including Mansfield) to split it into three species including the "broadheadae" form found in our area.\}

Common Name: Cusick's primrose

Family (Common Name): Primulaceae (Primrose Family)

Status: Former BLM Sensitive Species, Review Species

Flowering Period: March to May ppeak of flowering for most of our area is about midApril, higher elevations flower to mid-May\}

Habitat: Flowers when soil is still wet or moist. Ephemerally wet seeps, springs, and drainage-ways. Swales in sagebrush areas. Loam or especially heavy clay soils (with silver sage and camas as on Macon Flat).

Associates: Artemisia tridentata ssp. vaseyana, A. cana, ‥ papposa, Purshia tridentata, Festuca idahoensis, Dodecatheon spp., Camassia spp.

Key Characteristics: Plants 2-9 cm tall, 1-3 flowered; corolla about $1 \mathrm{~cm}$ long, bluish-violet to purplish, fornices lacking on throat. After flowering leaves form a small rosette.

Threats: Heavy grazing in spring, increasing housing developments, off-road vehicles.

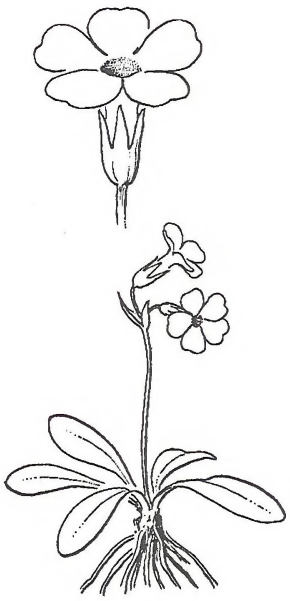


Scientific Name: Sphaeromeria potentilloides (A. Gray) A. Heller \{ Tanacetum potentilloides var. nitrophilum Cronquist\}

Common Name: Cinquefoil tansy

Family (Common Name): Asteraceae (Sunflower Family)

Status: BLM Sensitive Species, ID State Priority 2 Species

Flowering Period: May to July

Habitat: Edge of vernal pools or vernally moist alkaline flats and seepage areas. Usually on clay or clay loam soil which is rock hard by August. Up to $2100 \mathrm{~m}\left(6500^{\prime}\right)$ elevation.

Key Characteristics: Looks like a small sagebrush. Perennial herb from a compact caudex or short taproot; stems lax, 0.5-3 dm tall; herbage silky-tomentose; basal leaves tufted, petiolate, with pinnatifid or pinnately dissected blade less than $1 \mathrm{dm}$ long, the ultimate segments commonly ca $1 \mathrm{~mm}$ wide; heads pedunculate, the disk commonly $5-11 \mathrm{~mm}$ wide; receptacle dome-shaped, densely villous with soft, curly white hairs ca 0.5 to nearly $1 \mathrm{~mm}$ long; achenes becoming mucilaginous when wet.

Threats: Livestock grazing and trampling, and loss of vernal pools.

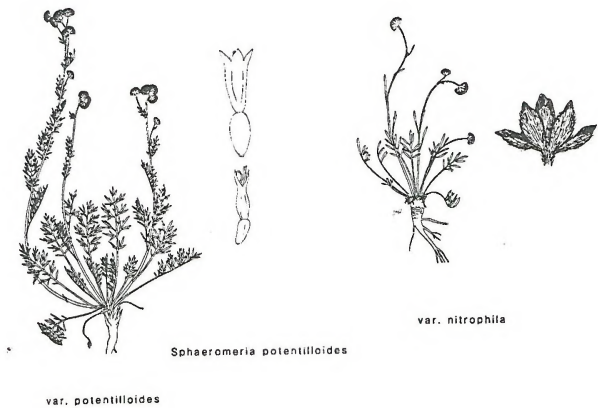


Scientific Name: Spiranthes diluvialis Sheviak

Common Name: Ute lady's tresses

Family (Common Name): Orchidaceae (Orchid Family)

Status: Federally listed as Threatened, G2

Flowering Period: Late July to September.

Habitat: Along streams, bogs, and open seepage areas, above the zone of complete saturation (standing water) but where ground is moist through capillary action yearround. Habitat is regularly flooded. Generally between $1000 \mathrm{~m}$ and $2000 \mathrm{~m}$ (3000' $6000^{\prime}$ ) elevation, below steep gradient, fast flowing streams and above flat gradient, meandering streams. Canopy is open.

Associates: Agrostis (redtop), Eleocharis (spike-rush), Habenaria (bog-orched, rein-orchid) \{similar in appearence\}, Elaeagnus (silverberry), Triglochin (arrow-grass), and Salix exigua (coyote willow).

Key Characteristics: Stems $20-50 \mathrm{~cm}$ tall; leaves linear, mostly basal, rapidly reduced to sheathing bracts; inflorescence a spike, $3-15 \mathrm{~cm}$ long; flowers ascending, rather long and slender, whitish to ivory-colored, lip ovate to lanceolate or oblong in outline and prominently expanded in lateral view, sepals connate at base for a short distance (or sometimes free), hood rarely evident.

Threats: Livestock grazing, vegetation removal, excavation, building construction, stream channelization, and hydroelectric development.
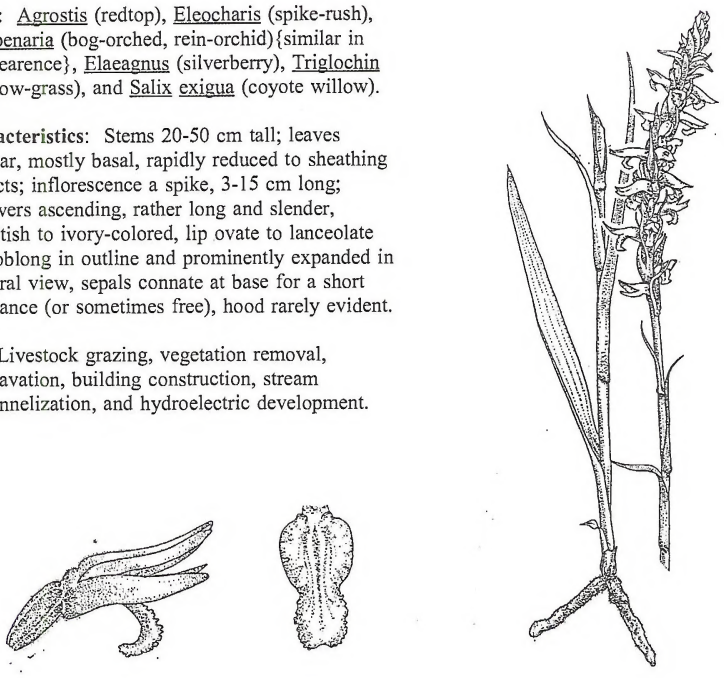
Scientific Name: Sporobolus asper (Michx.) Kunth

Common Name: Tall dropseed (rough dropseed)

Family (Common Name): Poaceae (Grass Family)

Status: BLM Sensitive Species, ID State Priority 1 Species

Flowering Period: August to September

Habitat: Usually in dry, sandy soils of prairies and foothills. 100 year floodplain terrace.

Associates: Aristida spp. (threeawn), Sporobolus cryptandrus (sand dropseed), Stipa comata (needle-and-thread grass), Oryzopsis hymenoides (Indian ricegrass).

Key Characteristics: Perennial, 5-12 dm tall; spikelets one flowered, $3.5-6 \mathrm{~mm}$ long, anthers $1.5-2.5$ mm long; glumes shorter than lemma; lemma awnless, one nerved; spike-like panicle terminal and axillary, pale or whitish, sometimes purplish, $5-15 \mathrm{~cm}$ long.

Threats: Only 2 known locations in Idaho, livestock grazing and trampling.

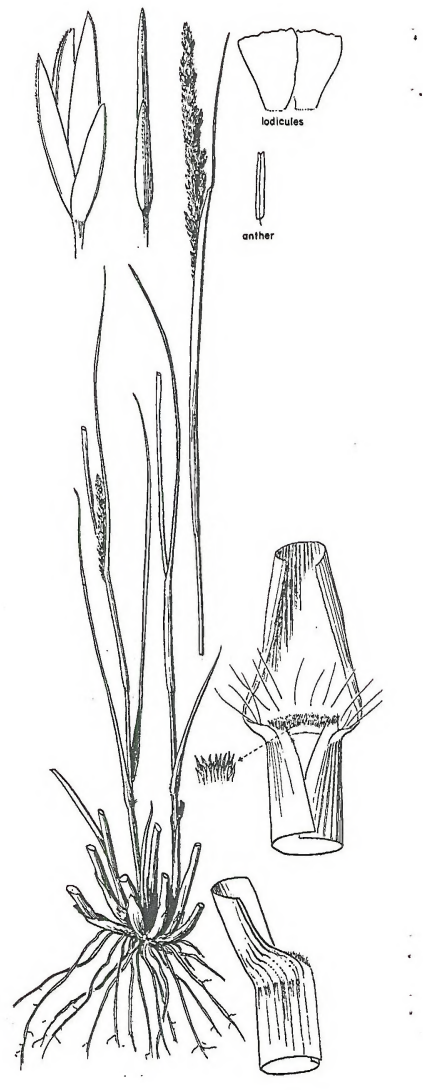


Scientific Name: Texosporium sancti-jacobi (Tuck.) Nadv.

Common Name: Woven-spore lichen

Class (Common Name): Ascomycytes (Fungi)

Status: BLM Sensitive Species, Globally Rare Species

Flowering Period: Fruits year round.

Habitat: Usually found on clumps of organic material, especially clumps of dead Poa secunda, or humus. Heavy clay soil. Open areas with high light intensity. Low elevation, dry sites. In native plant communities.

Associates: Old growth Artemisia tridentata ssp. wyomingensis, Poa secunda, Agropyron

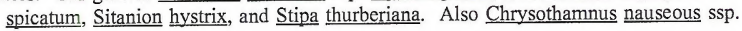
consimilis.

Key Characteristics: Yellow-green fruiting body (apothecia: a cup-shaped structure) with white to yellowish rims; grows adnate to the soil or over humus. The ascus (sac-like structure that encloses the ascospores) essentially dissolves and the paraphyses (filamentous outgrowths occurring among the reproductive organs) wrap around the ascospore, giving it a woven textured appearance (when observed at $400 \mathrm{x}$ ). The lichen surface is white with a cracked appearance (called areolate). Individual spores are dumbell shaped (septate: divided by a septum) and black.

Threats: Fire, livestock grazing, human disturbance, land development, and air pollution.

Note: This species has not been found in the Shoshone Resource Area to date.

Photo by Roger Rosentreter:

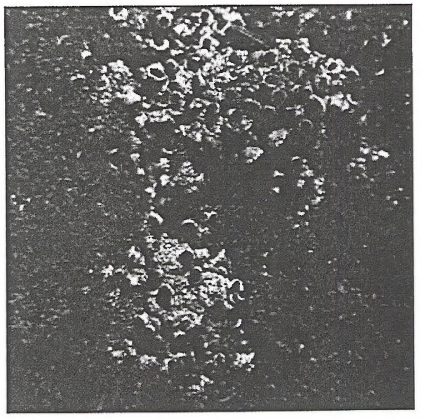



. 


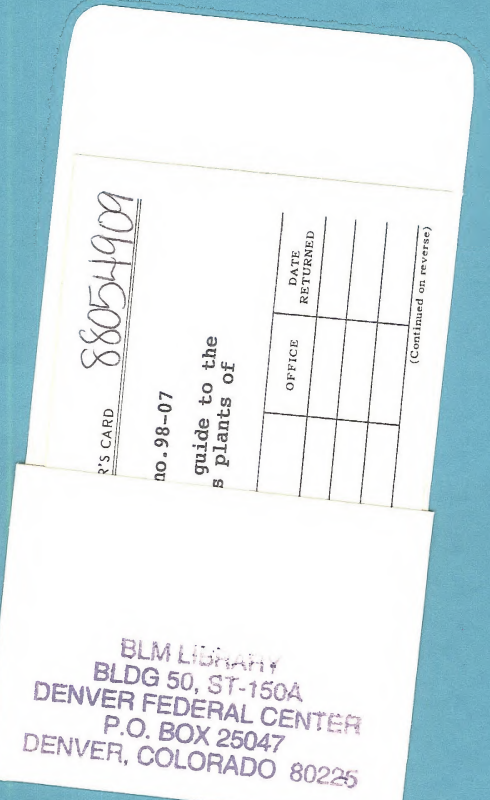




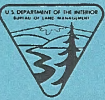

Bureau of Land Management Idaho State Office 1387 S. Vinnell Way

Boise, Idaho 83709

BLM/ID/PT-98/011+1150 